\title{
Oridonin enhances $\gamma$-globin expression in erythroid precursors from patients with $\beta$-thalassemia via activation of p38 MAPK signaling
}

\author{
LISHAN GUO $^{1 *}$, JIA CHEN $^{2 *}$, QIANYING WANG ${ }^{3}$, JUNLIANG ZHANG ${ }^{1}$ and WEIMIN HUANG ${ }^{1}$ \\ ${ }^{1}$ Department of Neonatology, Nanfang Hospital, Southern Medical University, Guangzhou, Guangdong 510515; \\ ${ }^{2}$ Department of Neonatology, Pediatric Clinics of Guangdong Women and Children Hospital, Guangzhou, Guangdong 510000; \\ ${ }^{3}$ Department of Pediatrics, Nanfang Hospital, Southern Medical University, Guangzhou, Guangdong 510515, P.R. China
}

Received September 24, 2018; Accepted September 20, 2019

DOI: $10.3892 / \mathrm{mmr} .2019 .10848$

\begin{abstract}
Upregulation of fetal hemoglobin expression can alleviate the severity of $\beta$-thalassaemia. This study aimed to investigate the effects of Oridonin (ORI, a diterpenoid compound) on $\gamma$-globin expression in human erythroid precursor cells and the potential underlying mechanisms. Erythroid precursor cells were enriched from 12 patients with $\beta$-thalassaemia by two-phase culture. The cells were then treated with different doses of ORI and the survival of erythroid precursor cells was determined. In addition, the expression levels of $\gamma$-globin and potential mechanisms were analyzed by reverse transcription-quantitative PCR, western blotting and chromatin immunoprecipitation. Treatment with $0.5 \mu \mathrm{M}$ ORI preferably enhanced $\gamma$-globin expression and exhibited little cytotoxicity. Similar to sodium butyrate (NaB, a histone deacetylase inhibitor), ORI significantly increased p38 mitogen-activated protein kinase (MAPK) activation, $\gamma$-globin expression, histone $\mathrm{H} 3$ and $\mathrm{H} 4$ acetylation at the $\mathrm{G} \gamma$ - and A $\gamma$-globin promoters, and cAMP-response element binding protein 1 (CREB1) phosphorylation. These effects were significantly mitigated by treatment with SB23580, a p38 MAPK inhibitor, in erythroid precursor cells. Therefore, ORI may effectively enhance $\gamma$-globin expression by activating p38 MAPK and CREB1, leading to histone modification in $\gamma$-globin gene promoters during the maturation of erythroid precursor cells. These findings suggested that ORI may be a novel and potential therapeutic agent for the treatment of $\beta$-thalassaemia.
\end{abstract}

Correspondence to: Dr Lishan Guo, Department of Neonatology, Nanfang Hospital, Southern Medical University, 1838 Guang Zhou Da Dao North, Guangzhou, Guangdong 510515, P.R. China E-mail:nfyygls@163.com

*Contributed equally

Key words: $\beta$-thalassemia, Oridonin, $\gamma$-globin, fetal hemoglobin, p38 mitogen-activated protein kinase, histone acetylation, cAMP-response element binding protein

\section{Introduction}

$\beta$-thalassemia is an inherited disease that affects several organ systems, leading to a relatively short lifespan $(1,2)$. $\beta$-thalassemia is particularly prevalent in the Mediterranean, Africa and Southeast Asia (3). Pathophysiologically, $\beta$-thalassemia is characterized by insufficient hemoglobin $\beta$-chain expression and excess $\alpha$-chain accumulation, resulting in ineffective erythropoiesis and chronic hemocytolysis (4). Patients with $\beta$-thalassemia are dependent on frequent blood transfusions, which leave them at risk of transfusion-transmitted infections and iron overload-related tissue damage (5). Currently, allogeneic bone marrow transplantation can cure the disease; however, the limited availability of suitable bone marrow donors, high cost and potential graft-versus-host responses limit its clinical application (6). Gene editing and therapy may be promising approaches for treatment of $\beta$-thalassemia, but they still are at an early stage (6). Therefore, the development of novel therapies for intervention of $\beta$-thalassemia is urgently required.

Epidemiological surveys have demonstrated that high levels of fetal hemoglobin $(\mathrm{HbF}, \alpha 2 \gamma 2)$ are inversely associated with the severity of clinical symptoms in patients with $\beta$-thalassemia (7). Therefore, reactivation of $\gamma$-globin gene expression is a therapeutic strategy for the treatment of $\beta$-thalassemia (8). There are three categories of $\mathrm{HbF}$ inducers: Ribonucleotide reductase inhibitors, short-chain fatty acids and cytotoxic agents (9). Hydroxyurea (HU), a ribonucleotide reductase inhibitor, has been approved by the United States Food and Drug Administration (FDA) for the treatment of sickle cell disease (SCD) (7). However, its therapeutic efficacy in $\beta$-thalassemia remains contentious $(8,10,11)$. Several compounds have been discovered to induce $\mathrm{HbF}$ or $\gamma$-globin gene expression in human erythroleukemic K562 cells, erythroid cells, primates and even in patients (12-15). However, these substances either have a short half-life in vivo, cytotoxicity, apparent carcinogenicity or induce hematopoietic suppression (12). Therefore, the discovery of new safe reagents for inducing $\mathrm{HbF}$ or $\gamma$-globin gene expression may be of significance in the management of patients with $\beta$-thalassemia. 
Previous studies have reported that some natural compounds from medical herbs can induce $\gamma$-globin gene expression with little toxicity (16-19). Oridonin (ORI) is a tetracycline diterpenoid from the traditional Chinese medicine Rabdosia rubescens, which has anti-tumor, immunomodulatory and neuroprotective activities (20-26). Previous studies have demonstrated that induction of $\mathrm{HbF}$ expression is associated with activation of $\mathrm{p} 38$ mitogen-activated protein kinase (MAPK) (27-29) and activated p38 MAPK can further activate cAMP response element binding 1 (CREB1), which can bind to specific sites in the $\gamma$-globin gene promoters to induce its expression $(30,31)$. In addition, histone modification is a known regulator of gene expression (32). Given that ORI can activate p38 MAPK in some types of cancer cells $(20,25)$, it was hypothesized that ORI may also activate p38 MAPK and CREB1 to induce histone modification and $\gamma$-globin gene expression in differentiating human erythroid precursor cells.

The present study purified and enriched human erythroid precursor cells from patients with $\beta$-thalassemia. Two-phase culture was employed to induce the differentiation of erythroid precursor cells, and the effects of ORI on $\gamma$-globin expression and the potential underlying mechanisms were analyzed.

\section{Materials and methods}

Subjects and cell culture. A total of 12 patients with $\beta$-thalassemia were recruited at the outpatient service of the Guangdong Women and Children Hospital between January 2015 and January 2016. The demographic and clinical characteristics of subjects are presented in Table I. Patients with $\beta$-thalassemia were diagnosed by laboratory blood tests and genetic examination. Patients were excluded from the study if they had received a blood transfusion during the past 3 months. Written informed consent was obtained from the patients' guardians and the experimental protocol was approved by the Ethical Committee of Guangdong Women and Children Hospital.

Peripheral venous blood samples were collected from the subjects. Blood mononuclear cells were isolated by Ficoll-Hypaque density gradient (GE Healthcare) centrifugation for $20 \mathrm{~min}$ at $400 \mathrm{x} \mathrm{g}$ and room temperature, and CD34 ${ }^{+}$ cells were purified using immunomagnetic beads, as previously described (33). The purified CD $34^{+}$cells were subjected to two-phase liquid culture, as previously described (34). Briefly, CD34+ cells were cultured for 7 days (phase I culture) in minimal essential media (MEM; Gibco; Thermo Fisher Scientific, Inc.) supplemented with $10 \%$ fetal bovine serum (FBS; Biological Industries), $1 \mu \mathrm{g} / \mathrm{ml}$ cyclosporin A (Sandoz AG) and $10 \%$ conditioned medium from cultures of bladder carcinoma 5,637 cells (American Type Culture Collection) at $37^{\circ} \mathrm{C}$ in an atmosphere containing $5 \% \mathrm{CO}_{2}$ and $95 \%$ humidity. The non-adherent cells were harvested, washed and cultured (phase II culture) for 7 days in fresh medium supplemented with $30 \% \mathrm{FBS}, 10^{-5} \mathrm{M} \beta$-mercaptoethanol, $10^{-6} \mathrm{M}$ dexamethasone, $300 \mu \mathrm{g} / \mathrm{ml}$ holo-transferrin (Sigma-Aldrich; Merck $\mathrm{KGaA}$ ), $10 \mathrm{ng} / \mathrm{ml}$ human recombinant stem cell factor and $1 \mathrm{U} / \mathrm{ml}$ human recombinant erythropoietin (Ortho Pharmaceutical Corp.).

On day 6 of phase II culture, the cells were treated in triplicate with vehicle ( $0.1 \%$ DMSO), ORI (Chengdu Must Bio-Technology Co., Ltd.) at $0.1,0.2,0.5$ or $1.0 \mu \mathrm{M}$, or $500 \mu \mathrm{M}$ sodium butyrate ( $\mathrm{NaB}$, a histone deacetylase inhibitor; Sigma-Aldrich; Merck KGaA). The number of viable cells in the different groups was counted by trypan blue dye exclusion assay daily from day 6 to day 14 in a blinded manner. Some cells were collected on day 12 and the relative mRNA expression levels of $\gamma$-globin and protein expression levels of $\mathrm{HbF}$ were determined by reverse transcription-quantitative PCR (RT-qPCR) and western blot analysis, respectively. For analysis of p38 MAPK signaling, some cells were pretreated with vehicle (control), $0.5 \mu \mathrm{M}$ ORI for $12,24,48,72$ or $96 \mathrm{~h}$, or $500 \mu \mathrm{M} \mathrm{NaB}$ for $48 \mathrm{~h}$ (as a positive control) to analyze the time-course of p38 MAPK activation. Some cells were pretreated with $10 \mu \mathrm{M}$ SB203580 (a p38 MAPK inhibitor; Promega Corporation) (35) for $30 \mathrm{~min}$ at room temperature and treated with ORI $(0.5 \mu \mathrm{M})$ or $\mathrm{NaB}(500 \mu \mathrm{M})$ for $48 \mathrm{~h}$. To evaluate the levels of CREB1, cells were treated with vehicle (control) or ORI $(0.5 \mu \mathrm{M})$ for $24,48,72$ or $96 \mathrm{~h}$, or with $500 \mu \mathrm{M} \mathrm{NaB}$ for $72 \mathrm{~h}$ (as a positive control) to analyze CREB1 time-dependent activation. Some cells were pretreated with $10 \mu \mathrm{M}$ SB203580 for $30 \mathrm{~min}$ at room temperature and treated with ORI $(0.5 \mu \mathrm{M})$ or $\mathrm{NaB}(500 \mu \mathrm{M})$ for $72 \mathrm{~h}$. In addition, western blot analysis and chromatin immunoprecipitation (ChIP) were performed in cells treated with ORI $(0.5 \mu \mathrm{M})$ and $\mathrm{NaB}(500 \mu \mathrm{M})$ for $72 \mathrm{~h}$, alone or in combination with SB203580 pre-treatment.

Trypan blue dye exclusion assay. The number of viable cells was determined by trypan blue dye exclusion assay. Briefly, human erythroid progenitor cells during phase II culture were treated with the indicated agents between days 6 and 14, and cell samples were collected daily or every other day. The cells were stained with $0.5 \%$ trypan blue at room temperature for 2 min and the number of unstained viable cells in the different groups was counted in a blinded manner.

$R T-q P C R$. Total RNA was extracted from different groups of cells using the RNeasy kit (Qiagen, Inc.). Following qualification and quantification, each RNA sample $(1 \mu \mathrm{g})$ was reverse transcribed into cDNA using oligo $(\mathrm{dT})_{18}$ and Moloney murine leukemia virus reverse transcriptase (Promega Corporation). The RT reactions were performed at $42^{\circ} \mathrm{C}$ for $60 \mathrm{~min}$, followed by $95^{\circ} \mathrm{C}$ for $5 \mathrm{~min}$ and $0-5^{\circ} \mathrm{C}$ for $5 \mathrm{~min}$. The relative levels of target gene mRNA transcripts normalized to control GAPDH were determined by RT-qPCR using the SYBR Green PCR Master Mix (Thermo Fisher Scientific, Inc.) and specific primers in a RT-PCR system (Applied Biosystems; Thermo Fisher Scientific, Inc.). The primer sequences were as follows: GAPDH, forward 5'-GCACCGTCAAGGCTGAGA AC-3', reverse 5'-TGGTGAAGACGCCAGTGGA-3'; $\alpha$-globin, forward 5'-TCCCCACCACCAAGACCTAC-3', reverse 5'-CCT TAACCTGGGCAGAGCC-3'; $\beta$-globin, forward 5'-CTCATG GCAAGAAAGTGCTCG-3', reverse 5'-AATTCTTTGCCA AAGTGATGGG-3'; and $\gamma$-globin, forward 5'-GGCAAC CTGTCCTCTGCCTC-3' and reverse 5'-GAAATGGATTGC CAAAACGG-3'. PCR was performed in triplicate at $95^{\circ} \mathrm{C}$ for $10 \mathrm{~min}$, followed by 40 cycles at $95^{\circ} \mathrm{C}$ for $10 \mathrm{sec}, 60^{\circ} \mathrm{C}$ for $20 \mathrm{sec}$ and $72^{\circ} \mathrm{C}$ for $15 \mathrm{sec}$. PCR was conducted using an ABI7500 PCR system (cat. no. 4351104; Applied Biosystems; Thermo Fisher Scientific, Inc.). The data were normalized to GAPDH and analyzed by $2^{-\Delta \Delta C q}(36)$. 
Table I. Demographic and clinical characteristics of subjects.

\begin{tabular}{rrrll}
\hline No. & Sex & Age (years) & \multicolumn{1}{c}{ Genotype } & Subgroup \\
\hline 1 & $\mathrm{M}$ & 7.2 & CD41-42/IVS-II-654 & Major \\
2 & $\mathrm{~F}$ & 13.0 & CD41-42/CD17 & Major \\
3 & $\mathrm{~F}$ & 12.3 & CD17/IVS-II-654 & Intermedia \\
4 & $\mathrm{M}$ & 2.5 & CD41-42/IVS-I-1 & Major \\
5 & $\mathrm{~F}$ & 8.0 & CD41-42/CD41-42 & Major \\
6 & $\mathrm{~F}$ & 2.3 & IVS-II-654/-28 & Intermedia \\
7 & $\mathrm{~F}$ & 8.0 & IVS-II-654/-28 & Intermedia \\
8 & $\mathrm{~F}$ & 6.5 & CD17/IVS-II-654 & Intermedia \\
9 & $\mathrm{M}$ & 10.0 & CD41-42/CD41-42 & Major \\
10 & $\mathrm{M}$ & 3.5 & $\beta \mathrm{BE} /-28$ & Intermedia \\
11 & $\mathrm{M}$ & 10.5 & $-28 /-28$ & Intermedia \\
12 & $\mathrm{~F}$ & 6.6 & $\beta \mathrm{E} / \mathrm{IVS}-\mathrm{II}-654$ & Intermedia \\
\hline
\end{tabular}

M, male; F, female.

Western blot analysis. The harvested cells were lysed on ice for $20 \mathrm{~min}$ in $50 \mathrm{mmol} / \mathrm{l}$ Tris- $\mathrm{HCl}(\mathrm{pH} 8), 150 \mathrm{mmol} / \mathrm{l} \mathrm{NaCl}$, $2 \%$ Nonidet P-40, $0.5 \%$ sodium deoxycholate, $0.02 \%$ sodium azide and $0.1 \%$ SDS supplemented with $10 \mathrm{mmol} / 1 \mathrm{PMSF}$. This was followed by centrifugation at $12,000 \mathrm{x} \mathrm{g}$ for $15 \mathrm{~min}$ at $4^{\circ} \mathrm{C}$. Following determination of protein concentrations using a Bradford assay (Bio-Rad Laboratories, Inc.), the cell lysate samples (30-50 $\mu \mathrm{g} /$ lane) were separated by SDS-PAGE on $15 \%$ gels and transferred to nitrocellulose membranes (EMD Millipore). The membranes were blocked with 5\% skimmed milk powder in TBS buffer containing $0.1 \%$ Tween for $2 \mathrm{~h}$ at room temperature and were incubated with the following primary antibodies: Sheep polyclonal anti-HbF (cat. no. ab19364; 1:1,000; Abcam), rabbit monoclonal anti-total (t)-p38 MAPK (cat. no. ab170099; 1:1,000; Abcam), mouse monoclonal anti-phosphorylated (p)-p38 MAPK (cat. no. ab45381; 1:1,000; Abcam), rabbit monoclonal anti-p-CREB1 (Ser 133; cat. no. 9198; 1:1,000; Cell Signaling Technology, Inc.), rabbit monoclonal anti-t-CREB1 (cat. no. 9197; 1:1,000; Cell Signaling Technology, Inc.) and mouse monoclonal anti- $\beta$-actin (cat. no. TA336770; 1:1,000; OriGene Technologies, Inc.) overnight at $4^{\circ} \mathrm{C}$. The bound antibodies were detected with horseradish peroxidase-conjugated rabbit anti-sheep IgG (H+L) (cat. no. 14-23-06; 1:5,000; KPL, Inc.), goat anti-rabbit IgG (H+L) (cat. no. ZB 2301; 1:5,000; OriGene Technologies, Inc.) and goat anti-mouse $\operatorname{IgG}(\mathrm{H}+\mathrm{L})$ (cat. no. ZB 2305; 1:5,000; OriGene Technologies, Inc.) and visualized using an enhanced chemiluminescent kit (Merck \& Co., Inc.), followed by densitometric analysis in the Bio-BEST-140E gel image system (SIM Company). The data were normalized to the control $\beta$-actin and the relative levels of $\mathrm{HbF}$, p38 MAPK and CREB1 expression and phosphorylation were determined using Glyko BandScan (Version 5.0; Glyko, Inc.) in the Bio-BEST-140E gel image system (SIM International).

ChIP. The impact of ORI on histone modification in the promoter regions of the $\mathrm{G} \gamma$ - and $\mathrm{A} \gamma$-globin genes was determined by ChIP using the EZ-ChIP kit (cat. no. 17-371; EMD
Millipore), according to the manufacturer's protocol (Upstate Biotechnology, Inc.; Thermo Fisher Scientific, Inc.). Briefly, $1 \times 10^{7}$ cells in the different groups were cross-linked with $1 \%$ formaldehyde for $10 \mathrm{~min}$ at room temperature under gentle agitation; cross-linking was terminated by the addition of $150 \mathrm{mM}$ Glycine for $5 \mathrm{~min}$. After the addition of SDS Lysis Buffer (cat. no. 20-163; EMD Millipore) containing Protease Inhibitor Cocktail II (cat. no. 20-238; EMD Millipore), according to the manufacturer's protocol, the cross-linked chromatins were sonicated five times at $100 \mathrm{~W}$ power in an ice bath (10 sec/sonication with $30 \mathrm{sec}$ between them), in order to obtain DNA fragments averaging 200-1,000 bp in size. One part of the supernatant fraction of chromatin without primary antibody treatment was saved as the 'input sample'. According to the manufacturer's protocol, in order to minimize the risk of contamination, the 'input sample' was divided into three samples. These samples were incubated with the antibody of interest [input; against acetyl-histone H3 (cat. no. 06-599; 1:100; EMD Millipore) or H4 (cat. no. 06-866; 1:300; EMD Millipore)], anti-RNA polymerase (positive control; 1:1,000; cat. no. 05-623; EMD Millipore) or normal mouse IgG (negative control; 1:1,000; cat. no. 12-371; EMD Millipore) overnight at $4^{\circ} \mathrm{C}$ with agitation. One tube without DNA sample was referred to as the 'No DNA' PCR control. These purified DNA samples and the 'No DNA' PCR control then underwent PCR using Control Primers (included in the EZ-ChIP kit; cat. no. 22-004; EMD Millipore), which are specific for the human GAPDH gene. The size of the GAPDH PCR product was $166 \mathrm{bp}$. After verification, the chromatins were probed with antibodies against acetyl-histone H3 (cat. no. 06-599; 1:100; EMD Millipore) and H4 (cat. no. 06-866; 1:300; EMD Millipore) overnight at $4{ }^{\circ} \mathrm{C}$ with agitation. The relative levels of the $\mathrm{G} \gamma$ - and $A \gamma$-globin promoter DNA fragments to the control Necdin were determined by RT-qPCR. The primer sequences were as follows: Necdin (control), forward 5'-GTC CTCTGCCTCTGCCATCA-3', reverse 5'-ATACAGGGCACT GGCCACTC-3'; G $\gamma$-globin, forward 5'-GTCCTCTGCCTC TGCCATCA-3', reverse 5'-ATACAGGGCACTGGCCAC TC-3'; and A $\gamma$-globin, forward 5'-TGTGGAAGATGCTGG AGGAG-3' and reverse 5'-ATACACAGGGCACTGGCCACT G-3'. The PCR products were visualized on a $2 \%$ agarose gel with ethidium bromide staining (Thermo Fisher Scientific, Inc.) and were semi-quantified; densitometric scanning was conducted using the Bio-BEST-140E gel image system (SIM International) and data were analyzed using Gel-Pro Analyzer 4.0 software (Media Cybernetics, Inc.).

Statistical analysis. Data are presented as the mean \pm standard deviation. The difference among groups was analyzed by one-way ANOVA, or repeated ANOVA where appropriate, followed by the least significant difference post hoc test using SPSS 13.0 (SPSS, Inc.). $\mathrm{P}<0.05$ was considered to indicate a statistically significant difference. When a P-value of 0.000 was achieved using the software it was designated as $\mathrm{P}<0.001$.

\section{Results}

ORI preferably enhances $\gamma$-globin expression during the maturation of erythroid precursor cells. To investigate the potential effect of ORI on the expression of $\gamma$-globin, human 
$\mathrm{CD}_{3}{ }^{+}$erythroid precursor cells were purified from patients with $\beta$-thalassaemia and subjected to two-phase culture. On day 6 of phase II culture, the cells were treated with vehicle alone (control), different doses of ORI or $500 \mu \mathrm{M} \mathrm{NaB}$ (classic inducer of $\mathrm{HbF}$ expression, positive control). Subsequently, the number of viably cultured cells was counted longitudinally. As demonstrated in Fig. 1A, treatment with $0.5 \mu \mathrm{M}$ ORI temporarily reduced the number of cultured cells on day 4 (from $3.77 \pm 0.21 \times 10^{6}$ to $3.36 \pm 0.37 \times 10^{6}$ cells $/ \mathrm{ml}$ ) and day 6 (from $4.30 \pm 0.24 \times 10^{6}$ to $3.89 \pm 0.39 \times 10^{6}$ cells $/ \mathrm{ml}$ ) post-culture, whereas treatment with $1 \mu \mathrm{M}$ ORI, similar to that of $\mathrm{NaB}$, further decreased the number of cultured cells 2 days after phase II culture. Cells were harvested on day 12, when the cells matured into orthochromatic normoblasts and enucleated erythrocytes (33). The relative levels of $\gamma$-globin mRNA transcripts normalized to the control GAPDH were determined by RT-qPCR (Fig. 1B). Treatment with different doses of ORI significantly increased the relative levels of $\gamma$-globin mRNA transcripts, which peaked following treatment with $0.5 \mu \mathrm{M}$ ORI (6.18 \pm 0.04 -fold; $\mathrm{P}<0.05)$ and were slightly reduced following treatment with 1.0 $\mu \mathrm{M}$ ORI $(4.57 \pm 0.20$-fold; $\mathrm{P}<0.05)$ in orthochromatic normoblasts and enucleated erythrocytes. Treatment with $\mathrm{NaB}$ also significantly increased the levels of $\gamma$-globin mRNA transcripts $(4.22 \pm 0.05$-fold; $\mathrm{P}<0.05)$; its effects were significantly stronger than those of $0.2 \mu \mathrm{M}$ ORI (3.04 \pm 0.16 -fold; $\mathrm{P}<0.05)$, but less than those of $1.0 \mu \mathrm{M}$ ORI in erythroid precursor cells. These findings indicated that ORI treatment enhanced $\gamma$-globin expression during the maturation of erythroid precursor cells.

Given that treatment with $0.5 \mu \mathrm{M}$ ORI strongly enhanced $\gamma$-globin expression and exerted little cytotoxicity, this dose was selected for further experiments. Further RT-qPCR analysis revealed that treatment with ORI did not significantly affect the relative mRNA expression levels of $\alpha$-globin (1.10 \pm 0.20 -fold; $\mathrm{P}=0.419)$ or $\beta$-globin $(1.00 \pm 0.24$-fold; $\mathrm{P}=0.971)$, but $\mathrm{did}$ significantly increase the relative mRNA expression levels of $\gamma$-globin $(6.42 \pm 0.57$-fold; $\mathrm{P}<0.05)$ in the cultured orthochromatic normoblasts and enucleated erythrocytes (Fig. 1C). However, treatment with $\mathrm{NaB}$ significantly increased the relative mRNA expression levels of $\alpha$-globin (2.02 \pm 0.50 -fold; $\mathrm{P}<0.05)$ and $\gamma$-globin $(4.27 \pm 0.76$-fold; $\mathrm{P}<0.05)$, but not $\beta$-globin $(1.22 \pm 0.43$-fold; $P=0.061)$ in the cultured cells. Western blotting indicated that treatment with ORI significantly increased the relative protein expression levels of $\mathrm{HbF}$ by $5.55 \pm 0.84$-fold $(\mathrm{P}<0.05)$, which was significantly higher than the $3.54 \pm 0.40$-fold increase in $\mathrm{HbF}$ induced by $\mathrm{NaB}$ in the cultured cells ( $\mathrm{P}=0.021$; Fig. 1D). Further western blot analysis indicated that treatment with $\mathrm{NaB}$, but not ORI, significantly increased the levels of $\alpha$-globin expression in the cultured cells (data not shown). Together, such data demonstrated that ORI treatment preferably enhanced $\gamma$-globin expression during the maturation of cultured erythroid precursor cells in vitro.

ORI enhances $\gamma$-globin expression, which is partially dependent on activation of p38 MAPK signaling in erythroid precursor cells. Previous studies have demonstrated that induction of $\mathrm{HbF}$ expression is associated with activation of p38 MAPK (26-29). To understand the molecular mechanisms underlying the action of ORI, erythroid precursor cells 1 day post-phase II culture were treated with ORI for 4 days or $\mathrm{NaB}$ for 2 days, and the relative levels of p38 MAPK expression and phosphorylation in the cells were determined by western blotting. As demonstrated in Fig. 2A, $12 \mathrm{~h}$ post-treatment with ORI, the relative ratios of p38 MAPK phosphorylation to its expression were significantly increased $(2.69 \pm 0.10$; $\mathrm{P}<0.05)$. The relative ratios of $\mathrm{p} 38$ MAPK phosphorylation to its expression peaked at $48 \mathrm{~h}$ post-treatment $(6.19 \pm 0.09$; $\mathrm{P}<0.05)$ and declined gradually at later time points. Similarly, treatment with $\mathrm{NaB}$ for $48 \mathrm{~h}$ significantly increased the relative ratios of p-p38 MAPK to t-p38 MAPK in cultured cells $(3.83 \pm 0.47 ; \mathrm{P}<0.05)$. Conversely, pretreatment with $10 \mu \mathrm{M}$ SB203580, a p38-specific inhibitor, significantly mitigated ORI- and NaB-induced p38 activation (Fig. 2B) and reduced $\gamma$-globin mRNA expression (Fig. 2C) and $\mathrm{HbF}$ protein expression in cultured cells (Fig. 2D). The levels of p38 phosphorylation, $\gamma$-globin mRNA expression and $\mathrm{HbF}$ protein expression in the SB203580-pretreated cells decreased to $34.82,42.07$ and $48.14 \%$ that of ORI-treated cells, respectively. Such data indicated that ORI-enhanced $\gamma$-globin expression was particularly dependent on activation of p38 MAPK in orthochromatic normoblasts and enucleated erythrocytes.

ORI treatment induces histone modification in $\gamma$-globin gene promoter regions by enhancing p38 MAPK signaling in erythroid precursor cells. Histone modification is a regulator of gene expression (31). To delineate the role of p38 MAPK-dependent epigenetic modifications in ORI-induced $\gamma$-globin gene expression, the cultured cells at 6 days post-phase II culture were treated with ORI or $\mathrm{NaB}$ in the presence or absence of SB23580 for $72 \mathrm{~h}$. The different groups of cells were harvested and cross-linked, and DNA fragments were prepared by sonication. The DNA fragments were identified by ChIP, using anti-acetyl-histone $\mathrm{H} 3$ and 4 for targeting and anti-RNA polymerase as a control. Subsequently, the precipitated DNA fragments in the $\mathrm{G} \gamma$ - and A $\gamma$-globin promoters were amplified by PCR. As demonstrated in Fig. 3A, purified DNA was then analyzed by PCR using Control Primers specific for the GAPDH promoter. The PCR product was observed in the positive control group (lane 3) and scarcely in the negative control group (lane 2). GAPDH promoter-specific DNA was also observed in the Input (lane 4) but not in the 'No DNA' PCR control (lane 1). Quantitative analysis indicated that the levels of acetylated histone $\mathrm{H} 3(\mathrm{acH} 3)$ and acetylated histone $\mathrm{H} 4$ (acH4) in the $\mathrm{G} \gamma$ - and $\mathrm{A} \gamma$-globin promoter regions in untreated cells were significantly higher than those of Necdin, a hallmark of specificity (Fig. 3B). The levels of $\mathrm{G} \gamma$-acH3 and $\mathrm{G} \gamma$-acH4 increased by $3.13 \pm 0.35$ - and 3.33 \pm 0.40 -fold, respectively $(\mathrm{P}<0.05)$, whereas $\mathrm{A} \gamma$-acH3 and $\mathrm{A} \gamma$-acH4 increased by 3.06 $\pm 0.36-$ and 3.28 \pm 0.41 -fold, respectively $(\mathrm{P}<0.05$; Fig. $3 \mathrm{C}$ and $\mathrm{D})$. Conversely, the levels of acH3 and acH4 at the $\mathrm{G} \gamma$ - and A $\gamma$-globin gene promoter regions in SB203580-pretreated cells were decreased by 54.31 and $50.45 \%$ for the $\mathrm{G} \gamma$-globin gene, and 51.93 and $47.88 \%$ for the $A \gamma$-globin gene, respectively, relative to cells treated with ORI alone. These findings indicated that ORI-enhanced $\gamma$-globin expression was partially mediated by p38 MAPK activation-dependent histone acetylation in cultured orthochromatic normoblasts and enucleated erythrocytes. 

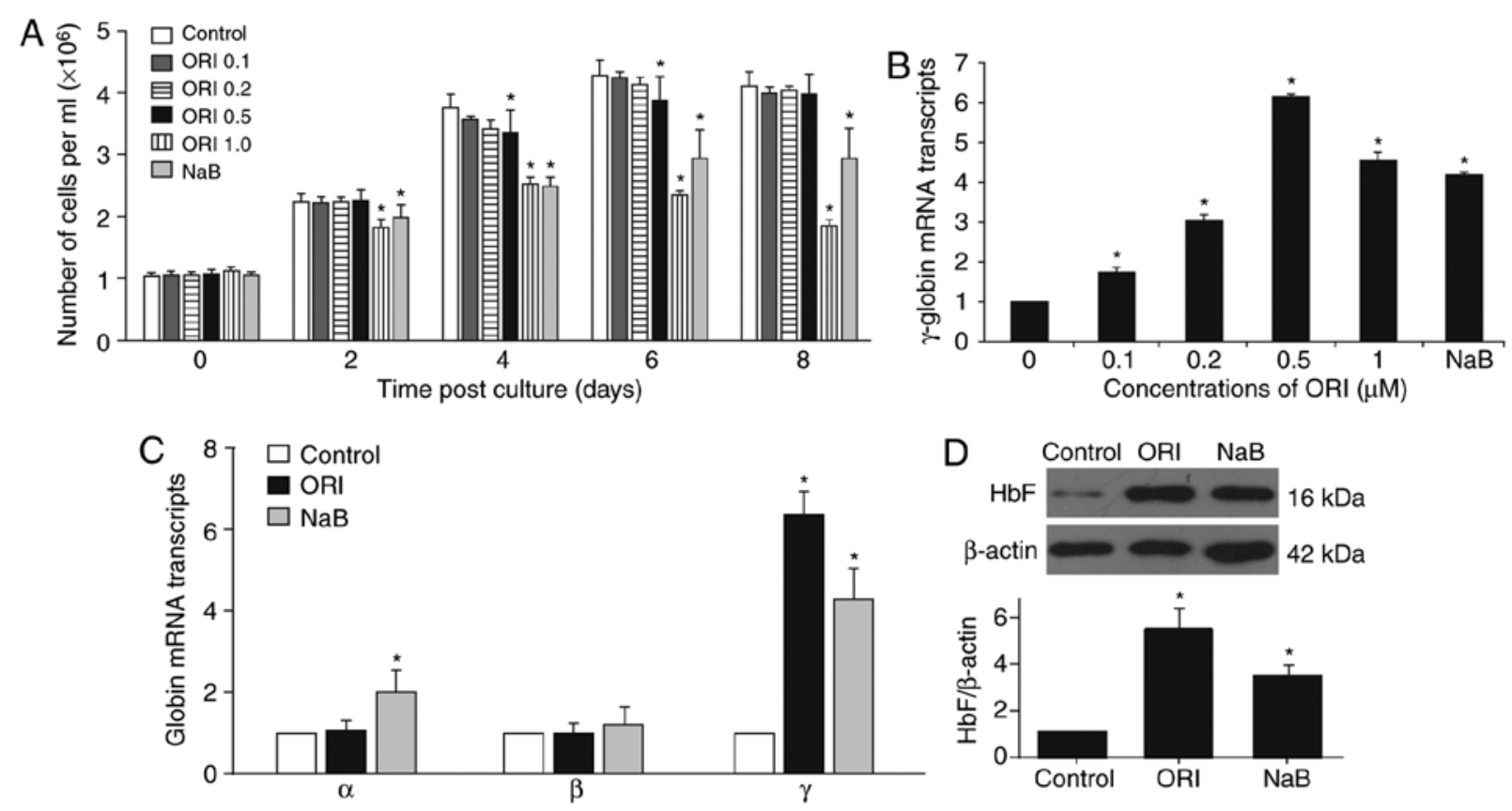

Figure 1. Treatment with ORI preferably induces $\gamma$-globin expression in cultured erythroid precursors from patients with human $\beta$-thalassemia. Peripheral blood mononuclear cells were cultured in a two-phase liquid culture system to enrich erythroid precursors and induce their differentiation. During phase II culture, the cells were treated with vehicle, or the indicated doses of ORI or NaB beginning on day 6 post-culture for varying time periods. The number of viable cells was counted longitudinally. On day 12 post-culture, the relative levels of $\alpha$-globin, $\beta$-globin and $\gamma$-globin mRNA transcripts, and HbF protein expression were determined by reverse transcription-quantitative PCR and western blot analysis. Data are representative images or expressed as the mean \pm standard deviation of each group of cells from at least five biological samples from three separate experiments. (A) ORI exhibited little cytotoxicity against the cultured cells. (B) Treatment with ORI increased $\gamma$-globin mRNA transcripts. (C) ORI preferably induced $\gamma$-globin mRNA transcription. (D) ORI treatment increased $\mathrm{HbF}$ protein expression. ${ }^{\mathrm{P}}<0.05$ vs. the control group. $\mathrm{HbF}$, fetal hemoglobin; $\mathrm{NaB}$, sodium butyrate; ORI, Oridonin.

ORI induces CREBI phosphorylation by activating p38 MAPK signaling in erythroid precursor cells. Previous studies have demonstrated that activation of p38 MAPK signaling by $\mathrm{NaB}$ augments $\gamma$-globin gene transcription through CREB1 $(29,30)$. The effects of ORI treatment on CREB1 activation in the cultured orthochromatic normoblasts and enucleated erythrocytes were analyzed by western blotting in this study. Treatment with ORI significantly increased the relative ratios of $\mathrm{p}$-CREB1 to $\mathrm{t}-\mathrm{CREB} 1$ in the cultured orthochromatic normoblasts and enucleated erythrocytes at $24 \mathrm{~h}$ post-treatment $(2.13 \pm 0.07$-fold; $\mathrm{P}<0.05)$; its effects peaked at $72 \mathrm{~h}$ post-treatment $(4.44 \pm 0.07$-fold; $\mathrm{P}<0.05)$ and then markedly declined to a level similar to the untreated control (1.10 \pm 0.03 -fold; $P=0.12$; Fig. 4A). Similarly, treatment with $\mathrm{NaB}$ for $72 \mathrm{~h}$ significantly increased CREB1 activation in the cultured cells $(4.35 \pm 0.11$-fold; $\mathrm{P}<0.05)$. However, treatment with SB23580 significantly reduced ORI or NaB-mediated CREB1 activation by 51.65 and $29.16 \%$ in the cultured orthochromatic normoblasts and enucleated erythrocytes (Fig. 4B). These findings suggested that ORI treatment activated p38 MAPK and CREB1, contributing to histone modification, and enhanced $\gamma$-globin expression in the cultured orthochromatic normoblasts and enucleated erythrocytes in vitro.

\section{Discussion}

Several natural products have been demonstrated to induce HbF expression in vitro and in vivo (15-17,19); however, the mechanisms underlying the action of these compounds have yet to be elucidated. The present study revealed that treatment with ORI significantly increased $\gamma$-globin expression with little cytotoxicity in cultured orthochromatic normoblasts and enucleated erythrocytes in vitro. In addition, treatment with ORI activated p38 MAPK and CREB1 signaling, which led to histone hyperacetylation and $\gamma$-globin expression in cultured orthochromatic normoblasts and enucleated erythrocytes. To the best of our knowledge, the present study was the first to demonstrate that ORI effectively induced $\gamma$-globin expression in cultured orthochromatic normoblasts and enucleated erythrocytes. This, together with little cytotoxicity, suggests that ORI may be a promising candidate for intervention in $\beta$-thalassemia.

An ideal $\mathrm{HbF}$ inducer should effectively induce $\mathrm{HbF}$ production and have no cytotoxicity against the differentiated erythrocytes (37). HU is a ribonucleotide reductase inhibitor, which has been approved by the FDA for treatment of SCD (7). However, this treatment fails to achieve a significant increase in the levels of $\mathrm{HbF}$ to prevent complications in patients with $\beta$-thalassemia $(38,39)$. The notable hematopoietic suppression induced by $\mathrm{HU}$ has hindered the management of $\beta$-thalassemia (12). The present study demonstrated that treatment with ORI at $0.1-0.5 \mu \mathrm{M}$ significantly increased the expression levels of $\gamma$-globin in cultured primary erythroid progenitor cells obtained from patients with $\beta$-thalassemia in a dose-dependent manner. However, treatment with $1 \mu \mathrm{M}$ ORI decreased its effect on inducing $\gamma$-globin expression. This, together with a reduction of $\sim 50 \%$ in the number of viable cells suggested that treatment with a higher dose of ORI may trigger apoptosis of erythroid progenitor cells. In addition, ORI treatment did not enhance $\alpha$ - and $\beta$-globin expression in cultured 

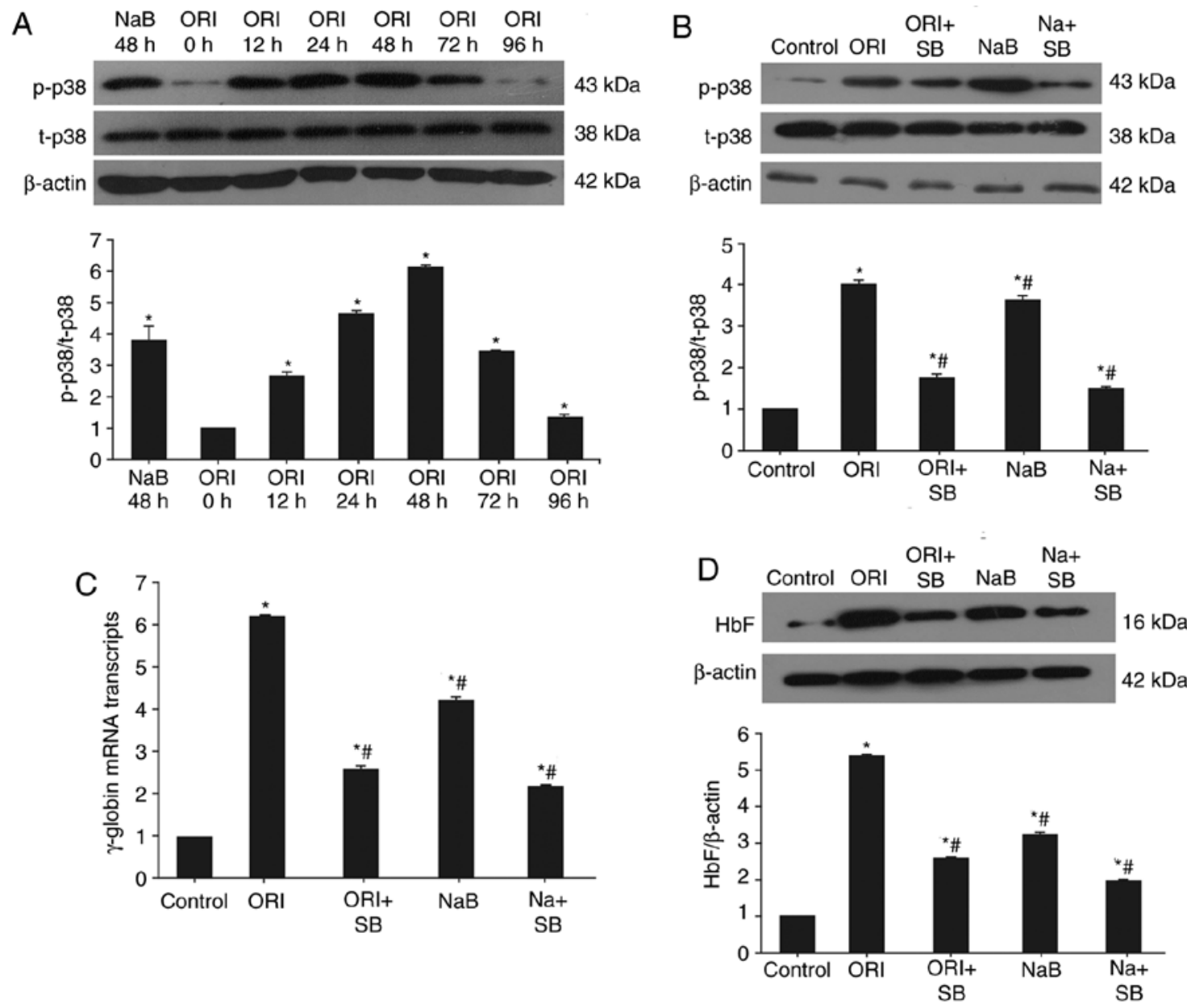

Figure 2. ORI treatment activates p38 MAPK to induce $\gamma$-globin expression in cultured erythroid precursor cells. (A) On day 6 of the phase II culture, the cells were treated with vehicle (control), $0.5 \mu \mathrm{M}$ ORI for the indicated time periods or $500 \mu \mathrm{M} \mathrm{NaB}$ for $48 \mathrm{~h}$. (B-D) Some cells were pretreated with, or without, SB203580 for $30 \mathrm{~min}$ and treated with $0.5 \mu \mathrm{M}$ ORI or $500 \mu \mathrm{M} \mathrm{NaB}$ for $48 \mathrm{~h}$. The relative levels of p38 MAPK expression and phosphorylation, $\gamma$-globin mRNA expression and HbF protein expression were determined by western blot analysis and reverse transcription-quantitative PCR. (B) ORI or NaB activated p38 MAPK, which was mitigated by SB203580. (C) ORI induced $\gamma$-globin and (D) HbF expression, which was partially dependent on p38 MAPK activation. Data are representative images or expressed as the mean \pm standard deviation of each group of cells from at least five biological samples from three separate experiments. " $\mathrm{P}<0.05$ vs. the control group. ${ }^{~} \mathrm{P}<0.05$ vs. $0.5 \mu \mathrm{M}$ ORI alone. MAPK, mitogen-activated protein kinase; NaB, sodium butyrate; ORI, Oridonin; SB, SB203580.

primary erythroid progenitor cells, and this preference may prevent the counteracting effect of some $\mathrm{HbF}$ inducers $(15,40)$. Notably, ORI at $0.5 \mu \mathrm{M}$ exhibited little inhibition on the viability of cultured primary erythroid progenitor cells Rabdosia rubescens, the herb from which ORI is extracted, has an excellent safety profile (41-44). Therefore, the present study suggested that ORI may be safe for intervention in patients with $\beta$-thalassemia in the clinic.

Previous studies have demonstrated that activation of the p38 MAPK signaling pathway is crucial for inducing $\gamma$-globin expression (27-30,45,46). MAPK kinase (MKK)3 and MKK6 are p38 MAPK activators, which can also independently induce $\mathrm{HbF}$ production (44). The present study revealed that ORI activated p38 MAPK signaling in a time-dependent manner, and inhibition of p38 MAPK signaling mitigated or abrogated ORI-induced increases in $\gamma$-globin expression in the cultured erythroid progenitors. Such data indicated that ORI-induced $\gamma$-globin expression partially depended on $\mathrm{p} 38$ MAPK activation in the cultured erythroid progenitors. Previous studies have demonstrated that some $\gamma$-globin inducers, such as
HU, thalidomide, butyrate and trichostatin A can promote reactive oxygen species (ROS) production to activate p38 MAPK signaling, increasing $\gamma$-globin expression $(27,47,48)$. ORI has been reported to induce the apoptosis of some cancer cells by enhancing the ROS-mediated p38 MAPK signaling $(49,50)$. Accordingly, it is possible that ORI may enhance ROS production to activate p38 MAPK and enhance $\gamma$-globin expression. More studies are required to determine the precise mechanisms underlying the pharmacological action of ORI.

It is notable that histone modification, particularly hyperacetylation, is important for enhancing gene expression. The present study demonstrated that ORI treatment significantly increased the levels of acetyl $\mathrm{H} 3$ and $\mathrm{H} 4$ in the $\mathrm{A} \gamma$ - and $\mathrm{G} \gamma$-globin promoter regions and activated CREB1 in cultured orthochromatic normoblasts and enucleated erythrocytes; these effects were abrogated by the inhibition of p38 MAPK signaling. The findings of the present study extended previous observations and indicated that enhancement of histone acetylation or inhibition of histone deacetylases can promote $\gamma$-globin expression by activating p38 MAPK signaling $(29,31,46)$. It is 
A
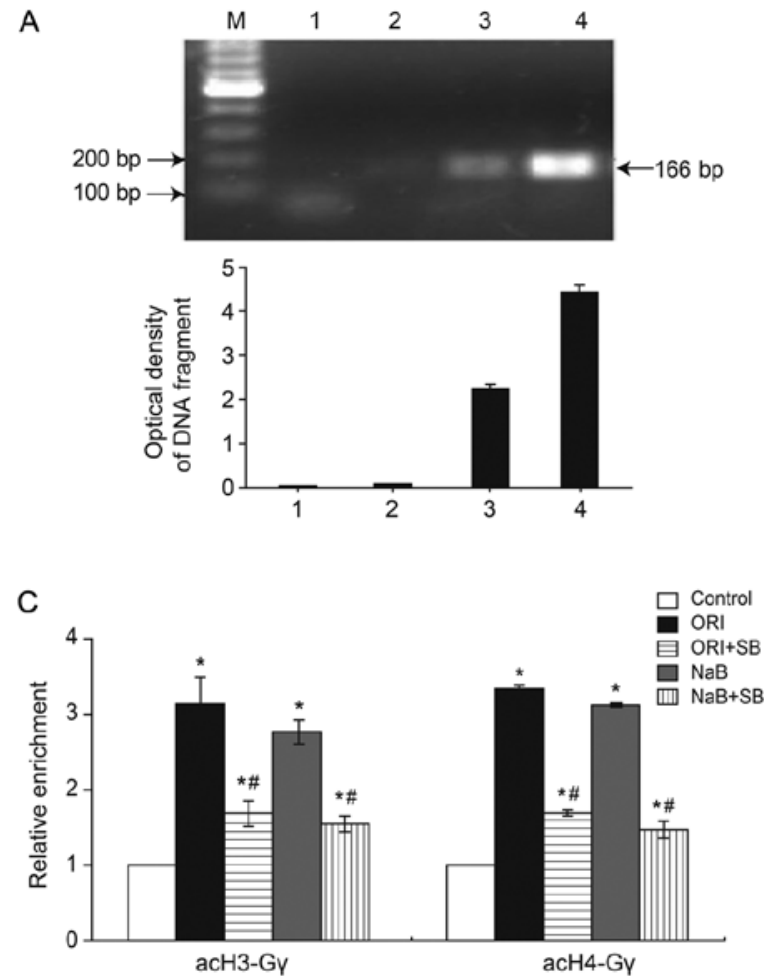

B
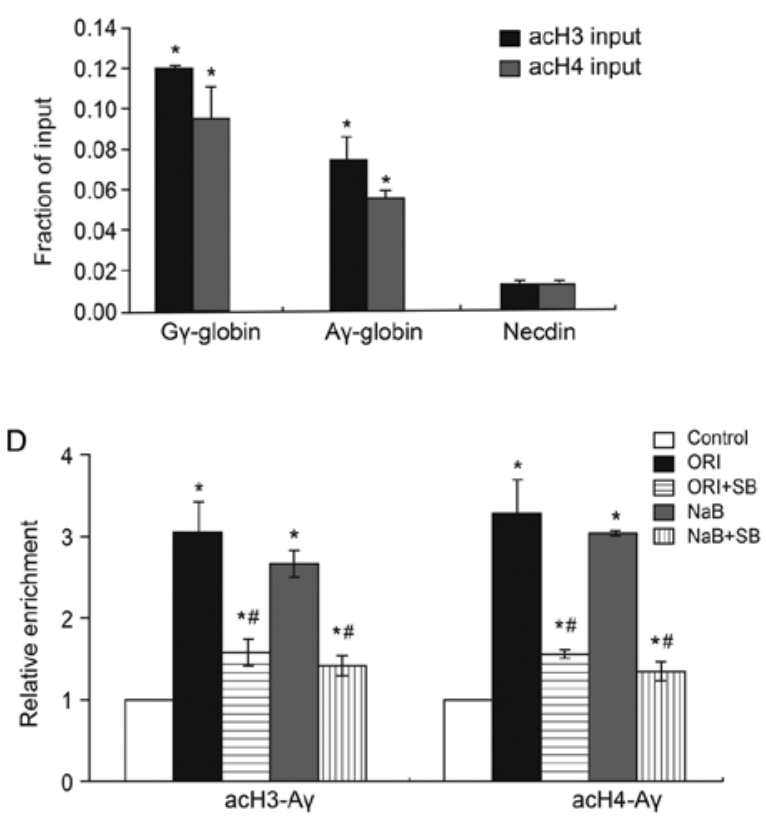

Figure 3. ORI induces hyperacetylation in the $\gamma$-globin promoter, which is partially dependent on p38 MAPK. On day 6 of the phase II culture, cells were pretreated with, or without, SB203580 for 30 min and treated with $0.5 \mu \mathrm{M}$ ORI or $500 \mu \mathrm{M} \mathrm{NaB}$ for $72 \mathrm{~h}$. Their chromatins were prepared and subjected to ChIP using acH3 and acH4 antibodies. The obtained DNA fragments were amplified by PCR using specific primers for the G $\gamma$-globin and A $\gamma$-globin promoters. Data are representative images or expressed as the mean \pm standard deviation of each group of cells from at least five biological samples from three separate experiments. (A) Identification of PCR products by agarose gel electrophoresis. 1: 'no DNA' PCR control; 2: normal mouse IgG ChIP; 3: anti-RNA polymerase II ChIP; 4: Input DNA. (B) Amplification of the G $\gamma$-globin and $\mathrm{A} \gamma$-globin and control in the input samples. Amplification of the AcH3 and Ach4 in the (C) $\mathrm{G} \gamma$-globin and (D) A $\gamma$-globin promoters. " $\mathrm{P}<0.05$ vs. the control group. ${ }^{*} \mathrm{P}<0.05$ vs. $0.5 \mu \mathrm{M}$ ORI alone. acH3, anti-acetyl-histone; acH4, anti-acetyl-histone H4; ChIP, chromatin immunoprecipitation; MAPK, mitogen-activated protein kinase; NaB, sodium butyrate; ORI, Oridonin; SB, SB203580.
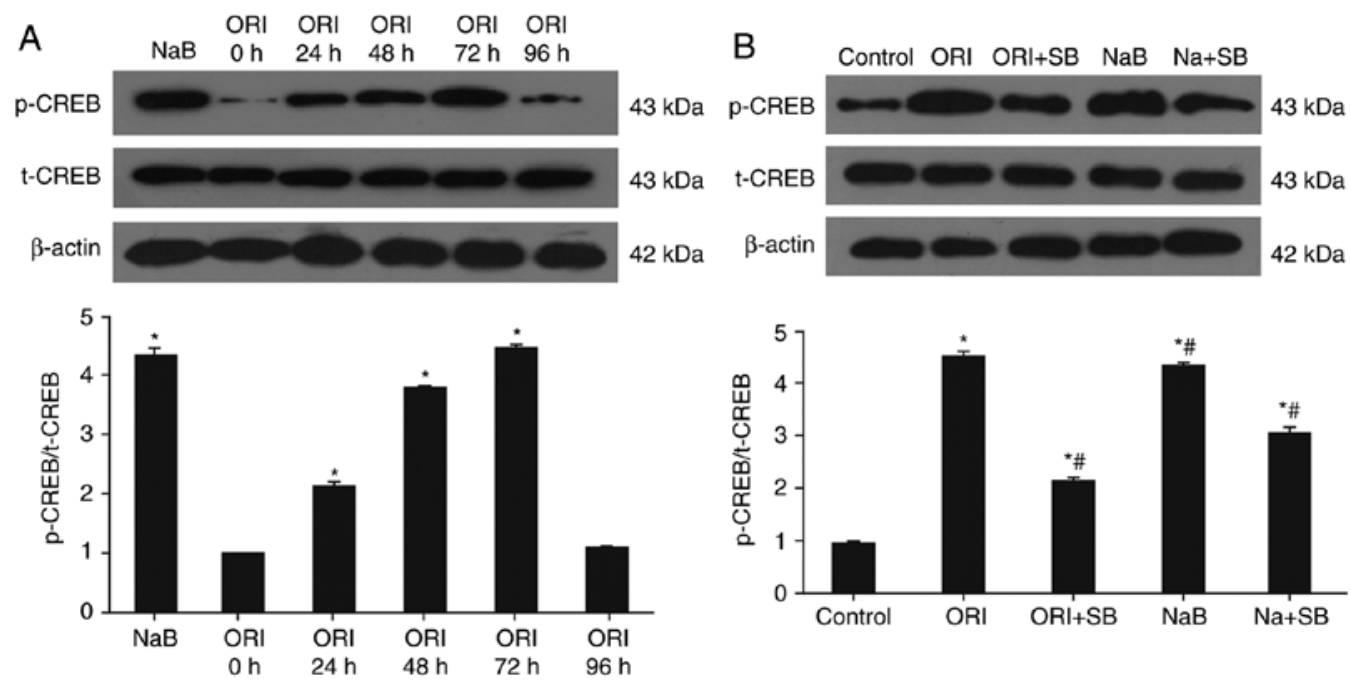

Figure 4. ORI activates CREB1, which is partially dependent on p38 MAPK activation. On day 6 of phase II culture, cells were pretreated with, or without, SB203580 for $30 \mathrm{~min}$ and treated with $0.5 \mu \mathrm{M}$ ORI for $96 \mathrm{~h}$ or $500 \mu \mathrm{M} \mathrm{NaB}$ for $72 \mathrm{~h}$. The relative levels of CREB1 phosphorylation and expression were determined longitudinally or tested after treatment by western blotting. Data are representative images or expressed as the mean \pm standard deviation of each group of cells from at least five biological samples from three separate experiments. (A) ORI activated CEB1 in a time-dependent manner. (B) ORI activated CREB1, which was partially dependent on $\mathrm{p} 38 \mathrm{MAPK}$ activation at $72 \mathrm{~h}$ post-treatment. ${ }^{*} \mathrm{P}<0.05$ vs. the control group. ${ }^{\#} \mathrm{P}<0.05 \mathrm{vs}$. $0.5 \mu \mathrm{M}$ ORI alone. CREB1, cAMP-response element binding protein 1; MAPK, mitogen-activated protein kinase; NaB, sodium butyrate; ORI, Oridonin; p-, phosphorylated; SB, SB203580; t-, total.

notable that activated CREB1 is crucial for $\gamma$-globin expression $(29,30)$ and that the motif sequence for activated CREB1 binding is located in the G $\gamma$-globin promoter (G-CRE, 5'-TGA CGTCA-3', -1,222 to -1,229) $(35,40)$. Accordingly, activation of 
CREB1 by ORI suggests that ORI may activate p38 MAPK, which subsequently activates CREB1 to induce histone hyperacetylation, increasing $\gamma$-globin expression in cultured orthochromatic normoblasts and enucleated erythrocytes. Therefore, the findings of the present study may provide novel insights into regulation of the $\gamma$-globin expression in human orthochromatic normoblasts and enucleated erythrocytes. Further studies may investigate whether treatment with ORI can direct or indirectly increase the interaction of CREB1 with the G-CRE in the $\mathrm{G} \gamma$-globin promoter.

In summary, the results of the present study indicated that ORI treatment selectively induced $\gamma$-globin expression with little cytotoxicity. ORI treatment induced epigenetic histone modification at the $\gamma$-globin promoter by activating p38 MAPK and CREB1. Therefore, ORI may be considered a promising therapeutic agent for intervention of $\beta$-thalassemia. Notably, the present study had limitations, including a small sample size, and a lack of in vivo studies and morphological investigation; in particular, morphological analysis was not conducted to confirm that cells developed into orthochromatic normoblasts and enucleated erythrocytes on day 12 , and this study did not assess whether the addition of ORI arrested erythrocyte maturation. Although the present study provided data to indicate the therapeutic potentials of ORI, further studies with a larger population are warranted to validate the findings and explore the mechanisms underlying the pharmacological action of ORI in enhancing $\gamma$-globin expression.

\section{Acknowledgements}

Not applicable.

\section{Funding}

This work was supported by grants from the Medical Scientific Research Foundation of Guangdong Province of China (grant no. 2019085) and Presidential Foundation of the Nanfang Hospital, Southern Medical University (grant no. 2014C013).

\section{Availability of data and materials}

The datasets used and/or analyzed during the current study are available from the corresponding author on reasonable request.

\section{Authors' contributions}

LSG conceived and designed the study and wrote the manuscript. JC performed the experiments, collected the data and wrote the manuscript. QYW, JLZ and WMH collected and analyzed the data. All of the authors read and approved the final manuscript.

\section{Ethics approval and consent to participate}

Written informed consent was obtained from the patients' guardians. The experimental protocol was approved by the Ethical Committee of Guangdong Maternal and Child Health Hospital.

\section{Patient consent for publication}

The patients' guardians provided consent for publication.

\section{Competing interests}

The authors declare that they have no competing interests.

\section{References}

1. Musallam KM, Cappellini MD, Wood JC, Motta I, Graziadei G, Tamim $\mathrm{H}$ and Taher AT: Elevated liver iron concentration is a marker of increased morbidity in patients with $\beta$ thalassemia intermedia. Haematologica 96: 1605-1612, 2011.

2. La Nasa G, Argiolu F, Giardini C, Pession A, Fagioli F, Caocci G, Vacca A, De Stefano P, Piras E, Ledda A, et al: Unrelated bone marrow transplantation for beta-thalassemia patients: The experience of the Italian Bone Marrow Transplant Group. Ann N Y Acad Sci 1054: 186-195, 2005.

3. Galanello R and Origa R: Beta-thalassemia. Orphanet J Rare Dis 5: 11, 2010.

4. Yuan J, Bunyaratvej A, Fucharoen S, Fung C, Shinar E and Schrier SL: The instability of the membrane skeleton in thalassemic red blood cells. Blood 86: 3945-3950, 1995.

5. Berger K, Ajani UA, Kase CS, Gaziano JM, Buring JE, Glynn RJ and Hennekens $\mathrm{CH}$ : Light-to-moderate alcohol consumption and the risk of stroke among U.S. male physicians. N Engl J Med 341: 1557-1564, 1999.

6. Rachmilewitz EA and Giardina PJ: How I treat thalassemia. Blood 118: 3479-3488, 2011.

7. Ley TJ: The pharmacology of hemoglobin switching: Of mice and men. Blood 77: 1146-1152, 1991.

8. Lettre G and Bauer DE: Fetal haemoglobin in sickle-cell disease: From genetic epidemiology to new therapeutic strategies. Lancet 387: 2554-2564, 2016.

9. Atweh G and Fathallah H: Pharmacologic induction of fetal hemoglobin production. Hematol Oncol Clin North Am 24: 1131-1144, 2010.

10. Banan M: Hydroxyurea treatment in $\beta$-thalassemia patients: To respond or not to respond? Ann Hematol 92: 289-299, 2013.

11. Ronchi A and Ottolenghi S: To respond or not to respond to hydroxyurea in thalassemia: A matter of stress adaptation? Haematologica 98: 657-659, 2013.

12. Paikari A and Sheehan VA: Fetal haemoglobin induction in sickle cell disease. Br J Haematol 180: 189-200, 2018.

13. Inati A, Kahale M, Perrine SP, Chui DH, Taher AT, Koussa S, Abi Nasr T, Abbas HA and Ghalie RG: A phase 2 study of HQK-1001, an oral fetal haemoglobin inducer, in $\beta$-thalassaemia intermedia. Br J Haematol 164: 456-458, 2014.

14. Ronzoni L, Sonzogni L, Fossati G, Modena D, Trombetta E, Porretti L and Cappellini MD: Modulation of gamma globin genes expression by histone deacetylase inhibitors: An in vitro study. Br J Haematol 165: 714-721, 2014.

15. Musallam KM, Taher AT, Cappellini MD and Sankaran VG: Clinical experience with fetal hemoglobin induction therapy in patients with $\beta$-thalassemia. Blood 121: 2199-2212, 2013.

16. Bianchi N, Zuccato C, Lampronti I, Borgatti M and Gambari R: Fetal Hemoglobin Inducers from the Natural World: A novel approach for identification of drugs for the treatment of \{beta\}-thalassemia and sickle-cell Anemia. Evid Based Complement Alternat Med 6: 141-151, 2009.

17. Fibach E, Bianchi N, Borgatti M, Prus E and Gambari R: Mithramycin induces fetal hemoglobin production in normal and thalassemic human erythroid precursor cells. Blood 102: 1276-1281, 2003.

18. Ng NY and Ko CH: Natural remedies for the treatment of beta-thalassemia and sickle cell Anemia-current status and perspectives in fetal hemoglobin reactivation. Int Sch Res Notices 2014: 123257, 2014.

19. Theodorou A, Phylactides M, Forti L, Cramarossa MR, Spyrou P, Gambari R, Thein SL and Kleanthous M: The investigation of resveratrol and analogs as potential inducers of fetal hemoglobin. Blood Cells Mol Dis 58: 6-12, 2016.

20. Bu HQ, Liu DL, Wei WT, Chen L, Huang H, Li Y and Cui JH: Oridonin induces apoptosis in SW1990 pancreatic cancer cells via p53- and caspase-dependent induction of p38 MAPK. Oncol Rep 31: 975-982, 2014. 
21. Owona BA and Schluesener HJ: Molecular insight in the multifunctional effects of oridonin. Drugs R D 15: 233-244, 2015.

22. Wang S, Zhang Y, Saas P, Wang H, Xu Y, Chen K, Zhong J, Yuan Y, Wang Y and Sun Y: Oridonin's therapeutic effect: Suppressing Th1/Th17 simultaneously in a mouse model of Crohn's disease. J Gastroenterol Hepatol 30: 504-512, 2015.

23. Zhang X, Chen LX, Ouyang L, Cheng Y and Liu B: Plant natural compounds: Targeting pathways of autophagy as anti-cancer therapeutic agents. Cell Prolif 45: 466-476, 2012.

24. Zhao G, Zhang T, Ma X, Jiang K, Wu H, Qiu C, Guo M and Deng G: Oridonin attenuates the release of pro-inflammatory cytokines in lipopolysaccharide-induced RAW264.7 cells and acute lung injury. Oncotarget 8: 68153-68164, 2017.

25. Wu QX, Yuan SX, Ren CM, Yu Y, Sun WJ, He BC and Wu K Oridonin upregulates PTEN through activating p38 MAPK and inhibits proliferation in human colon cancer cells. Oncol Rep 35: 3341-3348, 2016

26. Wang S, Yu L, Yang H, Li C, Hui Z, Xu Y and Zhu X: Oridonin attenuates synaptic loss and cognitive deficits in an A 11-42-induced mouse model of Alzheimer's disease. PLoS One 11: e0151397, 2016.

27. Aerbajinai W,Zhu J, GaoZ, Chin K and Rodgers GP: Thalidomide induces gamma-globin gene expression through increased reactive oxygen species-mediated p38 MAPK signaling and histone H4 acetylation in adult erythropoiesis. Blood 110: 2864-2871, 2007.

28. Pace BS, Liu L, Li B and Makala LH: Cell signaling pathways involved in drug-mediated fetal hemoglobin induction: Strategies to treat sickle cell disease. Exp Biol Med (Maywood) 240: 1050-1064, 2015.

29. Wei GH, Zhao GW, Song W, Hao DL, Lv X, Liu DP and Liang CC: Mechanisms of human gamma-globin transcriptional induction by apicidin involves p38 signaling to chromatin. Biochem Biophys Res Commun 363: 889-894, 2007.

30. Ramakrishnan V and Pace BS: Regulation of gamma-globin gene expression involves signaling through the p38 MAPK/CREB1 pathway. Blood Cells Mol Dis 47: 12-22, 2011.

31. Sangerman J, Lee MS, Yao X, Oteng E, Hsiao CH, Li W, Zein S, Ofori-Acquah SF and Pace BS: Mechanism for fetal hemoglobin induction by histone deacetylase inhibitors involves gamma-globin activation by CREB1 and ATF-2. Blood 108: 3590-3599, 2006.

32. Marx V: Epigenetics: Reading the second genomic code. Nature 491: 143-147, 2012.

33. Traycoff CM, Abboud MR, Laver J, Brandt JE, Hoffman R, Law P, Ishizawa L and Srour EF: Evaluation of the in vitro behavior of phenotypically defined populations of umbilical cord blood hematopoietic progenitor cells. Exp Hematol 22: 215-222, 1994.

34. Fibach E and Prus E: Differentiation of human erythroid cells in culture. Curr Protoc Immunol: Chapter 22: Unit 22F.7, 2005.

35. Cuenda A, Rouse J, Doza YN, Meier R, Cohen P, Gallagher TF, Young PR and Lee JC: SB 203580 is a specific inhibitor of a MAP kinase homologue which is stimulated by cellular stresses and interleukin-1. FEBS Lett 364: 229-233, 1995.

36. Livak KJ and Schmittgen TD: Analysis of relative gene expression data using real-time quantitative PCR and the 2(-Delta Delta C(T)) method. Methods 25: 402-408, 2001
37. Thein SL: The emerging role of fetal hemoglobin induction in non-transfusion-dependent thalassemia. Blood Rev 26 (Suppl 1): S35-S39, 2012.

38. Pourfarzad F, von Lindern M, Azarkeivan A, Hou J, Kia SK, Esteghamat F, van Ijcken W, Philipsen S, Najmabadi $H$ and Grosveld F: Hydroxyurea responsiveness in $\beta$-thalassemic patients is determined by the stress response adaptation of erythroid progenitors and their differentiation propensity. Haematologica 98: 696-704, 2013.

39. Rigano P, Pecoraro A, Calzolari R, Troia A, Acuto S, Renda D, Pantalone GR, Maggio A and Di Marzo R: Desensitization to hydroxycarbamide following long-term treatment of thalassaemia intermedia as observed in vivo and in primary erythroid cultures from treated patients. Br J Haematol 151: 509-515, 2010.

40. Fathallah H, Taher A, Bazarbachi A and Atweh GF: Differences in response to fetal hemoglobin induction therapy in beta-thalassemia and sickle cell disease. Blood Cells Mol Dis 43: 58-62, 2009.

41. Ma Z: Study on immune regulation of Rabdosia rubescens and its safety assessment (unpublished PhD thesis). Central South University, Public Health, 2010 (In Chinese).

42. Zang K, Du L, Liu X, Ma J and Ren Y: Therapeutic effect of oridonin tablet on acetic acid-induced ulcerative colitis in mice. Chin J Modern Applied Pharmacy 29: 781-785, 2012 (In Chinese).

43. Ma Z, Hu C and Zhang Y: Therapeutic effect of Rabdosia rubescens aqueous extract on chronic pharyngitis and its safety. Zhong Nan Da Xue Xue Bao Yi Xue Ban 36: 170-173, 2011 (In Chinese).

44. Deng Xu-xia and Lyu Xiang: Efficency compirson of Herba Rabidosiae Rubescentis dripping pills and Herba Rabdosiae Rubescentis buccal tablets in the treatment of recurrent oral ulcer. Henan Traditional Chin Med 37 (4): 2017 (In Chinese).

45. Mabaera R, West RJ, Conine SJ, Macari ER, Boyd CD, Engman CA and Lowrey $\mathrm{CH}$ : A cell stress signaling model of fetal hemoglobin induction: What doesn't kill red blood cells may make them stronger. Exp Hematol 36: 1057-1072, 2008.

46. Pace BS, Qian XH, Sangerman J, Ofori-Acquah SF, Baliga BS, Han J and Critz SD: p38 MAP kinase activation mediates gamma-globin gene induction in erythroid progenitors. Exp Hematol 31: 1089-1096, 2003.

47. Cokic VP, Andric SA, Stojilkovic SS, Noguchi CT and Schechter AN: Hydroxyurea nitrosylates and activates soluble guanylyl cyclase in human erythroid cells. Blood 111: 1117-1123, 2008.

48. Hsiao CH, Li W, Lou TF, Baliga BS and Pace BS: Fetal hemoglobin induction by histone deacetylase inhibitors involves generation of reactive oxygen species. Exp Hematol 34: 264-273, 2006.

49. Oh HN, Seo JH, Lee MH, Yoon G, Cho SS, Liu K, Choi H, Oh KB, Cho YS, Kim H, et al: Oridonin induces apoptosis in oral squamous cell carcinoma probably through the generation of reactive oxygen species and the p38/JNK MAPK pathway. Int J Oncol: Mar 16, 2018 doi: 10.3892/ijo.2018.4319 (Epub ahead of print)

50. Huang J, Wu LS, Tashiro S, Onodera S and Ikejima T: Reactive oxygen species mediate oridonin-induced HepG2 apoptosis through p53, MAPK, and mitochondrial signaling pathways. J Pharmacol Sci 107: 370-379, 2008. 